\title{
Pengaruh Penambahan Vitamin C dalam Pengencer Semen Sapi Limousin yang Dibekukan Terhadap Kualitas Post Thawing
}

\author{
Effect of Vitamin C Addition in the Extender on Post Thawing Quality Sperm of Frozen \\ Limousin Bull Semen
}

\author{
M. A. Yahaq, Y. S. Ondho dan Sutiyono \\ Fakultas Peternakan dan Pertanian, Universitas Diponegoro \\ Corresponding Author: abdillahyahaq@gmail.com
}

\begin{abstract}
The aim of this study was to find the effect of optimize vitamin $\mathrm{C}$ in to the extender on post thawing test of frozen Limousine bull semen. The materialof this research used semen ejaculate from 3 Limousine bull. The treatment of vitamin C $0 \mathrm{mg}$ (T0), vitamin C $250 \mathrm{mg} / 100 \mathrm{ml}$ (T1) and vitamin C $750 \mathrm{mg} / 100 \mathrm{ml}$ (T2) to skim milk - egg yolk extender. The statistic analysis Randomized Block Design (RBD) with 3 treatments and 3 groups. The parameters observed are semen motility, semen mortality (percentage of death) and semen abnormalities. Results of this research showed that vitamin $C$ on extender significantly affected $(P<0.05)$ on post thawing motility, but not significantly affected $(\mathrm{P}>0.05)$ on mortality and abnormalities. The highest sperm quality was achieved by addition of $250 \mathrm{mg}$ vitamin $\mathrm{C}$ to skim milk - egg yolk extender. On the basis of the present result it is concluded that vitamin $\mathrm{C}$ on skim milk - egg yolk extender have not been able to maintain the quality of post thawing semen.
\end{abstract}

Key words: Limousine bull semen, vitamin C, extender, semen quality, post thawing

\section{ABSTRAK}

Penelitian ini bertujuan untuk mengetahui pengaruh penambahan vitamin $C$ dalam pengencer skim kuning telur terhadap kualitas sperma post thawing. Materi yang digunakan adalah semen dari 3 ekor pejantan sapi Limousin. Setiap semen hasil penampungan dibagi menjadi 3 bagian kemudian masing-masing diencerkan dengan pengencer skim kuning telur yang ditambah vitamin C $0 \mathrm{mg}(\mathrm{T} 0)$, vitamin C $250 \mathrm{mg} / 100 \mathrm{ml}$ (T1) dan vitamin C $750 \mathrm{mg} / 100 \mathrm{ml}$ (T2). Parameter yang diamati adalah motilitas semen, mortalitas (persentase kematian) sperma dan abnormalitas sperma. Analisis yang digunakan adalah analisis ragam dan uji rata-rata Duncan. Hasil analisis data menunjukkan bahwa penambahan vitamin $\mathrm{C}$ dalam pengencer semen memberikan pengaruh nyata $(\mathrm{P}<$ $0,05)$ terhadap motilitas post thawing, namun tidak berpengaruh nyata $(\mathrm{P}>0,05)$ terhadap mortalitas dan abnormalitas. Kualitas semen terbaik ditunjukkan pada penambahan vitamin $\mathrm{C}$ sebanyak $250 \mathrm{mg}$ dalam pengencer skim kuning telur. Penambahan vitamin sampai C $750 \mathrm{mg} / 100 \mathrm{ml}$ pengencer skim kuning telur belum dapat mempertahankan kualitas semen post thawing.

Kata kunci: Semen sapi Limousin, vitamin C, pengencer, kualitas semen, post thawing

\section{PENDAHULUAN}

Kebutuhan terhadap protein hewani masyarakat semakin meningkat seiring bertambahnya penduduk. Upaya untuk memenuhi kebutuhan protein hewani masyarakat dapat dilakukan dengan cara meningkatkan produksi ternak penghasil daging. Ternak penghasil daging yang dikembangkan oleh para peternak di Indonesia salah satunya adalah sapi peranakan Limousin. Hal ini dikarenakan jenis sapi peranakan Limousin mempunyai karakteristik pertumbuhan yang cepat dengan bentuk tubuhnya yang amat panjang, sehingga mampu menghasilkan daging yang banyak (Suharyati dan Hartono, 2011).

Salah satu upaya meningkatkan populasi sapi peranakan Limousin (PL) yaitu dengan metode Inseminasi Buatan (IB) yang dilakukan dengan cara menyilangkan sapi betina lokal dengan semen pejantan Limousin. Metode Inseminasi Buatan merupakan metode perkawinan yang lebih efektif dan efisien dalam hal penggunaan semen beku untuk meningkatkan sapi persilangan dari pada perkawinan alami. Keberhasilan Inseminasi Buatan sangat 
ditentukan oleh kualitas semen beku yang digunakan (Mumu, 2009). Kualitas semen beku yang baik digunakan untuk IB harus memenuhi standar Post Thawing Motility (PTM) yang sudah ditetapkan yaitu sebesar $40 \%$ (Standar Nasional Indonesia). Maka dari itu, untuk mempertahankan kualitas semen yang akan dibekukan agar tetap terjaga selama dalam penyimpanan diperlukan pengencer yang mengandung nutrisi, anti cold shock, krioprotektan dan antioksidan yang dapat menjaga kualitas semen dalam proses ekuilibrasi hingga pembekuan (Wiratri et al., 2014).

Semen sapi Limousin di Balai Inseminasi Buatan (BIB) Ungaran menunjukkan penurunan motilitas yang tidak stabil terutama pada motilitas post thawing. Pengencer semen beku yang digunakan di Balai Inseminasi Buatan Ungaran sebenarnya sudah mengandung nutrisi, anti cold shock dan pencegah pengkristalan, namun belum ada penambahan bahan yang berfungsi sebagai antioksidan.

Salah satu antioksidan yang mampu untuk meningkatkan kualitas semen adalah vitamin C. Vitamin C memiliki kemampuan untuk menguatkan kestabilan jaringan membran plasma terhadap peroksidasi yang terjadi pada saat pengolahan semen beku, karena ada kontak langsung dengan $\mathrm{O}_{2}$ (oksigen) yang dapat menyebabkan kematian pada spermatozoa (Savitri et al., 2014). Tujuan penelitian ini adalah untuk mengetahui pengaruh penambahan vitamin $\mathrm{C}$ yang optimal dalam pengencer semen terhadap kualitas Post Thawing. Manfaat penelitian yaitu dapat menjadi dasar penambahan vitamin $\mathrm{C}$ yang baik pada pengencer semen dalam memperbaiki kualitas semen beku yang diproduksi.

\section{MATERI DAN METODE}

Penelitian ini dilakukan selama satu bulan di Balai Inseminasi Buatan (BIB) Ungaran, Kecamatan Sidomulyo, Kabupaten Semarang. Materi yang digunakan dalam penelitian ini adalah semen segar dari tiga pejantan sapi Limousin berumur 9 tahun, dengan volume semen sebesar 6-10 $\mathrm{ml}$ dan motilitas semen segar $70 \%$.

\section{a. Pembuatan bahan pengencer}

Bahan pengencer yang digunakan adalah susu skim - kuning telur yang terdiri dari susu skim, kuning telur, glukosa, penicillin, streptomycin, gliserol dan aquades. Pembuatan buffer dengan cara susu skim dilarutkan ke dalam aquadest dengan perbandingan 1 : 9 dan dipanaskan hingga suhu $92^{\circ} \mathrm{C}-95^{\circ} \mathrm{C}$ selama 10 menit. Selanjutnya pembuatan buffer antibiotik dengan menambahkan antibiotik berupa penicillin 1 flc dan streptomycin 3 flc yang dilarutkan ke dalam aquadest hingga $10 \%$ kemudian ditambahkan pada buffer susu skim yang telah didinginkan dengan perbandingan $1: 100$. Pengencer bagian A terdiri dari kuning telur $10 \%$, fruktosa $1 \%$ dan buffer antibiotik $89 \%$. Pengencer bagian B terdiri dari kuning telur $10 \%$, gliserol $16 \%$, fruktosa $1 \%$, berbagai penambahan vitamin $\mathrm{C}$ (V-C Injection) dan buffer antibiotik $73 \%$.

\section{b. Penampungan semen dan evaluasi semen}

Penampungan semen menggunakan vagina buatan dan teaser yang dilakukan 2 kali dalam 1 minggu yaitu pada hari senin dan kamis jam 07.30 - 09.30 WIB.

Setiap semen hasil penampungan segera dilakukan pemeriksaan kualitas semen secara makroskopis (warna, bau, konsistensi, $\mathrm{pH}$ dan volume) dan mikroskopis (motilitas individu, motilitas massa dan konsentrasi). Semen yang memiliki konsentrasi $>1000 \mathrm{x}$ $10^{7} / \mathrm{ml}$, volume $\geq 6 \mathrm{ml}$ dan motilitas progresif $70 \%$ digunakan sebagai sampel untuk dibuat menjadi semen beku.

\section{c. Pengenceran semen}

Setelah dilakukan evaluasi kualitas semen segar, kemudian dilakukan pembagian 3 kelompok masing-masing diencerkan dengan susu skim - kuning telur yang tidak ditambahkan vitamin C (T0). Penambahan vitamin $\mathrm{C}$ dosis $250 \mathrm{mg} / 100 \mathrm{ml}$ bahan pengencer (T1) dan T2 : Penambahan vitamin C dosis $750 \mathrm{mg} / 100 \mathrm{ml}$ bahan pengencer (T2). 


\section{d. Pendinginan, pengemasan dan} penyimpanan semen

Pendinginan semen yang telah diencerkan menggunakan cooltop suhu $5^{\circ} \mathrm{C}$ dalam jangka waktu 3 jam. Kemudian dilakukan pengemasan semen ke dalam straw $0,25 \mathrm{ml}$ dengan menggunakan mesin fillingsealing. Setelah itu, dilakukan pembekuan semen menggunakan mesin pembekuan hingga suhu $-140^{\circ} \mathrm{C}$ dan segera disimpan dalam container berisi nitrogen cair dengan suhu $-196^{\circ} \mathrm{C}$.

\section{e. Pemeriksaan semen post thawing}

Pemeriksaan semen post thawing dilakukan dengan mencairkan semen dalam air suhu $37^{\circ} \mathrm{C}$ selama 30 detik.

\section{Pemeriksaan motilitas}

Pemeriksaan motilitas dilakukan sesuai dengan standar BIB Ungaran. Persentase sperma motil ditentukan secara subjektif pada mikroskop perbesaran $100 \mathrm{X}$ dengan 5 lapang pandang.

\section{Pemeriksaan mortalitas}

Pemeriksaan mortalitas sperma menggunakan teknik pewarnaan eosin negrosin (2\%). Sperma yang mati akan menyerap warna dari eosin, sehingga warnanya kemerahan. Selanjutnya jumlah sperma yang mati dihitung dan dibagi dengan jumlah sperma yang dihitung (sperma mati + sperma hidup) sebanyak 200 sperma.

\section{Analisis Data}

Penelitian ini menggunakan Rancangan Acak Kelompok (RAK) dengan 3 perlakuan dan 3 ulangan. Data persentase yang diperoleh dianalisis menggunakan uji ANOVA, apabila terdapat perbedaan, maka dilanjutkan dengan uji berganda Duncan. Apabila analisis data menunjukkan koefisien keragaman > 20, maka dilakukan transformasi Arcsin (Sastrosupadi, 2000).

\section{HASIL DAN PEMBAHASAN}

\section{Kualitas Semen Segar Sapi Limousin}

Semen dari hasil penampungan dianalisis secara makroskopis (warna, bau, konsistensi, $\mathrm{pH}$ dan volume) dan mikroskopis (motilitas individu, motilitas massa dan konsentrasi). Semen yang memiliki kualitas dan kuantitas dengan volume $\geq 6 \mathrm{ml}$, warna putih krem, konsistensi sedang, bau spermin, $\mathrm{pH}$ 6,4 6,8, motilitas massa diatas ++ , motilitas progresif diatas $70 \%$ dan konsentrasi $>1000$ x $10 \%$ ml digunakan sebagai sampel untuk dibuat menjadi semen beku. Hasil pemeriksaan semen segar yang digunakan untuk semen beku ditunjukkan pada Tabel 1 .

Tabel 1. Rata-rata kualitas dan kuantitas semen segar sapi Limousin yang layak digunakan untuk semen beku.

\begin{tabular}{lccc}
\hline \multirow{2}{*}{ Kualitas } & \multicolumn{3}{c}{ Rata - rata Sd } \\
\cline { 2 - 4 } & Sapi A & Sapi B & Sapi C \\
\hline Volume (ml) & $8,00 \pm 0,44$ & $6,70 \pm 0,56$ & $7,03 \pm 0,50$ \\
Warna & Putih Krem & Putih Krem & Putih Krem \\
Konsistensi & Sedang & Sedang & Sedang \\
Bau & Spermin & Spermin & Spermin \\
pH & $6,47 \pm 0,12$ & $6,53 \pm 0,23$ & $6,67 \pm 0,12$ \\
Motilitas massa & ++ & ++ & ++ \\
Motilitas individu (\%) & $70,90 \pm 1,39$ & $70,50 \pm 0,50$ & $70,23 \pm 0,25$ \\
Konsentrasi $(10$ & $1616,33 \pm 156,18$ & $1579,67 \pm 113,78$ & $1420,67 \pm 48,64$ \\
spermatozoa/ml) & & & + \\
\hline
\end{tabular}


Berdasarkan Tabel 1 menunjukkan bahwa semen sapi Limousin A, B dan C yang digunakan penelitian memiliki rata-rata volume masing-masing $8,00 \pm 0,44 \mathrm{ml} ; 6,70$ $\pm 0,56 \mathrm{ml}$ dan 7,03 $\pm 0,50 \mathrm{ml}$. Volume semen tersebut lebih besar dari hasil penelitian Sumeidiana et al. (2007) yang menyatakan bahwa volume semen sapi Limousin memiliki rata-rata 5,42 $\pm 0,97 \mathrm{ml}$. Hasil penelitian Wiratri et al. (2014) menyatakan rata-rata volume semen sapi Limousin sebesar 6,75 $\pm 0,68 \mathrm{ml}$.

Menurut Hafez dan Hafez (2000) menyatakan bahwa kondisi fisiologis sapi dapat mempengaruhi volume semen dan kualitas semen. Semen sapi Limousin berwarna putih krem dengan tingkat konsistensi yang sedang dan memiliki bau khas semen yaitu spermin. Semen memiliki $\mathrm{pH}$ rata-rata sebesar $6,42 \pm 0,10$. Nilai $\mathrm{pH}$ tersebut tergolong dalam kisaran normal. Hasil penelitian Wiratri (2014) menunjukkan bahwa pH semen sapi Limousin sebesar 6,60 $\pm 0,16$.

\section{Motilitas Semen Post Thawing}

Motilitas semen setelah dicairkan kembali (Post Thawing Motility) merupakan pengujian quality control tahap terakhir sebelum semen didistribusikan. Motilitas semen post thawing yang akan didistribusikan harus memenuhi persyaratan yang telah ditetapkan. Standar Nasional Indonesia (2017) menunjukkan bahwa semen yang siap didistribusikan harus memiliki motilitas individu sebesar $\geq 40 \%$. Motilitas semen post thawing memiliki peranan penting karena dapat digunakan sebagai penilaian kemampuan sperma untuk membuahi sel telur dalam inseminasi buatan. Hasil rataan pemeriksaan motilitas semen post thawing dengan penambahan vitamin $\mathrm{C}$ dalam pengencer semen ditunjukkan pada Tabel 2.

Hasil analisis statistik pada Tabel 2 menunjukkan persentase motilitas post thawing antar perlakuan $\mathrm{T} 0, \mathrm{~T} 1$ dan $\mathrm{T} 2$ pada semen sapi A, B dan C berbeda nyata $(\mathrm{P}<0,05)$. Semen sapi A, B dan $\mathrm{C}$ yang diberi penambahan vitamin $\mathrm{C}$ T1 dengan rataan sebesar 43,41 lebih baik dibanding dengan T0 $\left(40,97^{\mathrm{b}}\right)$ dan T2 $\left(40,71^{\mathrm{b}}\right)$. Menurut Lubis et al. (2013) menyatakan bahwa penambahan vitamin $C$ dengan dosis 0,2 gram $/ 100 \mathrm{ml}$ pengencer susu skim kuning telur menghasilkan persentase motilitas semen yang terbaik.

Tabel 2. Rata-rata motilitas sperma post thawing dari pengencer menggunakan vitamin $\mathrm{C}$

\begin{tabular}{lccc}
\hline \multirow{2}{*}{ Pejantan } & \multicolumn{3}{l}{ Perlakuan } \\
\cline { 2 - 4 } & T0 & T1 & T2 \\
\hline & & $\ldots \ldots \ldots \ldots \ldots . .(\%) \ldots \ldots \ldots \ldots \ldots$ \\
Sapi A & 41,70 & 43,77 & 39,67 \\
Sapi B & 40,87 & 43,33 & 40,97 \\
Sapi C & 40,33 & 43,13 & 41,50 \\
Rata-rata & $40,97^{\mathrm{b}}$ & $43,41^{\mathrm{a}}$ & $40,71^{\mathrm{b}}$ \\
\hline
\end{tabular}

Superskrip huruf kecil yang berbeda pada baris yang sama menunjukkan adanya perbedaan nyata $(\mathrm{P}<0,05)$; $\mathrm{T} 0=$ Tanpa penambahan vitamin $\mathrm{C} ; \mathrm{T} 1=$ Vitamin $\mathrm{C}$ $250 \mathrm{mg} / 100 \mathrm{ml} ; \mathrm{T} 2=$ Vitamin $C 750 \mathrm{mg} / 100 \mathrm{ml}$.

Penambahan vitamin C dengan 250 $\mathrm{mg} / 100 \mathrm{ml}$ pengencer merupakan dosis yang optimal vitamin $\mathrm{C}$ untuk ditambahkan dalam pengencer susu skim kuning telur karena menunjukkan peningkatan dibandingkan tanpa penambahan vitamin C. Menurut Aurich et al. (1997) vitamin C dengan dosis $200 \mathrm{mg} / 100 \mathrm{ml}$ pengencer mampu berperan melindungi membran plasma kuda dari kerusakan membran plasma akibat peroksidasi yang disebabkan oleh radikal bebas. Pemberian dosis vitamin $\mathrm{C}$ yang tepat dalam pengencer dapat meningkatkan kualitas semen terutama motilitas semen dibandingkan pengencer tanpa penambahan antioksidan karena antioksidan berupa vitamin $\mathrm{C}$ mampu mencegah terjadinya peroksidasi lipid pada membran sel sperma dengan cara memadamkan atau menekan radikal bebas serta mampu mengakhiri siklus reaksi. Feradis (2009) menyatakan bahwa peroksidasi lipid dapat dicegah dengan menggunakan antioksidan sehingga mampu mencegah kerusakan membran sel sperma.

Penambahan vitamin C mampu meminimalkan kerusakan membran plasma sel sperma yang terjadi akibat reaksi 
peroksidasi. Menurut Lubis (2013) vitamin C juga mampu mengikat oksigen radikal dalam sperma sehingga dapat mencegah terbentuknya peroksidasi lipid yang menghambat glikolisis dan motilitas sperma. Penurunan motilitas semen terjadi pada penambahan vitamin $\mathrm{C}$ dosis $750 \mathrm{mg} / 100 \mathrm{ml}$ pengencer (T2). Penurunan tersebut disebabkan oleh penambahan dosis vitamin $\mathrm{C}$ yang terlalu banyak sehingga dapat menimbulkan toksik dan mempengaruhi laju oksidasi. Savitri et al. (2014) berpendapat bahwa dosis antioksidan yang terlalu banyak dapat berpengaruh terhadap laju oksidasi yang menyebabkan aktivitas antioksidan menghilang bahkan antioksidan yang berlebihan dapat menjadi prooksidan.

Nilai persentase motilitas post thawing dapat disebabkan oleh berbagai faktor diantaranya nutrisi dalam bahan pengencer,kondisi fisologis lingkungan dan reaksi peroksidasi akibat radikal bebas. Rizal et al. (2002) berpendapat bahwa sperma memerlukan nutrisi untuk proses metabolisme yang menghasilkan energi berupa ATP sehingga mampu untuk meningkatkan daya gerak (motilitas) sperma.

Tabel 3. Rata-rata mortalitas sperma post thawing dari pengencer skim kuning telur + Vit. C

\begin{tabular}{cccc}
\hline & \multicolumn{3}{c}{ Perlakuan } \\
\cline { 2 - 4 } Pejantan & T0 & T1 & T2 \\
\hline & $\ldots \ldots \ldots \ldots \ldots . .(\%) \ldots \ldots \ldots \ldots \ldots . .$. \\
Sapi A & 9,55 & 10,06 & 19,67 \\
Sapi B & 9,94 & 8,46 & 10,49 \\
Sapi C & 12,08 & 8,29 & 13,42 \\
Rata-rata & 10,52 & 8,93 & 14,52 \\
\hline
\end{tabular}

\section{Persentase Kematian Semen (Mortalitas) Post Thawing}

Mortalitas sperma merupakan persentase kematian sel sperma yang dapat dihitung dengan cara membandingkan antara sel sperma mati dengan total sel sperma yang dinyatakan dalam persentase. Kematian yang terjadi pada sel sperma dapat diakibatkan oleh kerusakan membran plasma. Kerusakan membran plasma terjadi akibat reaksi peroksidasi oleh radikal bebas. Membran plasma yang mengalami kerusakan dapat meningkatkan resiko kematian pada sel sperma sehingga meningkatkan persentase kematian sperma. Penambahan antioksidan dalam pengencer semen diperlukan untuk melindungi membran plasma sel sperma. Hasil pemeriksaan mortalitas sperma semen beku yang menggunakan pengencer skim kuning telur yang ditambahkan vitamin $\mathrm{C}$ disajikan pada Tabel 3.

Hasil analisis pemeriksaan mortalitas sperma pada Tabel 3 menunjukkan hasil antar perlakuan tidak signifikan. Tidak ada perbedaan mortalitas antar perlakuan tersebut disebabkan oleh penambahan antioksidan berupa vitamin $\mathrm{C}$ belum mampu memperbaiki daya hidup setelah dibekukan. Fungsi vitamin $\mathrm{C}$ yang ditambahkan dalam pengencer semen mampu melindungi membran plasma sperma dari kerusakan yang disebabkan peroksidasi oleh radikal bebas.

Tabel 3 menunjukkan bahwa mortalitas sperma post thawing paling rendah terdapat pada perlakuan $\mathrm{T} 1$ dengan rataan sebesar 8,93 . Hasil tersebut lebih rendah dibanding dengan hasil rataan perlakuan T0 sebesar 10,52 dan T2 sebesar 14,52. Menurut Feradis (2009), peroksidasi dapat merusak struktur lipid pada membran plasma sperma sehingga menyebabkan kematian sel sperma. Mortalitas dapat dipengaruhi oleh kurangnya antioksidan yang terdapat dalam bahan pengencer seperti vitamin C. Savitri et al. (2014) menyatakan bahwa vitamin C dalam bahan pengencer mampu mencegah reaksi peroksidasi lipid pada membran plasma sperma akibat dari radikal bebas, sehingga mampu mengurangi persentase kematian sperma.

Penambahan vitamin $\mathrm{C}$ yang terlalu banyak dapat merubah kondisi $\mathrm{pH}$ dalam pengencer semen, sehingga semen menjadi asam.

Kondisi asam tersebut dapat meningkatkan persentase kematian sel sperma. Kematian sel sperma tersebut dikarenakan pada kondisi asam dapat meningkatkan tekanan osmotik pada cairan semen. Akibatnya dapat terjadi ketidakseimbangan tekanan osmotik antara didalam 
dan diluar sel sperma. Rosmaidar (2013) menyatakan bahwa bertambahnya sel sperma yang rusak dan mati diakibatkan oleh $\mathrm{pH}$ semen dan akibat pendinginan.

Peningkatan tekanan osmotik disebut dengan hipertonik. Hipertonik terjadi akibat dari meningkatnya ion hidrogen dalam semen karena $\mathrm{pH}$ yang menurun oleh asam laktat. Asam laktat dalam pengencer meningkat akibat dari proses metabolisme yang meningkat. Menurut Maulida (2014), persentase kematian sel sperma dapat disebabkan oleh peningkatan tekanan osmotik atau hipertonik, sehingga permeabilitas membran plasma sperma menurun, dan terjadi perpindahan cairan dari dalam sel sperma menuju keluar tubuh sperma.

Tekanan osmotik yang menurun disebut hipotonik, yaitu cairan diluar sel sperma yang mampu memasuki sel sperma yang dapat menimbulkan kerusakan pada sel sperma sehingga mampu mematikan fungsi organel sel sperma. Tambing (2000) menyatakan bahwa ketidakseimbangan konsentrasi intraseluler dan ekstraseluler dapat mengakibatkan dehidrasi sel sperma.

\section{KESIMPULAN}

Berdasarkan hasil penelitian dapat disimpulkan bahwa penambahan vitamin $\mathrm{C}$ sebesar $250 \mathrm{mg} / 100 \mathrm{ml}$ dalam pengencer susu skim kuning telur mampu mempertahankan persentase motilitas post thawing yang tinggi dan persentase mortalitas post thawing yang rendah.

\section{UCAPAN TERIMAKASIH}

Penulis mengucapkan terimakasih kepada Balai Inseminasi Buatan (BIB) Ungaran atas dukungan materi percobaan dan fasiltas pendukung lainnya sehingga penelitian ini berjalan dengan baik.

\section{DAFTAR PUSTAKA}

Akhter, S., B. A. Rakha, M. S. Ansari, S. M. H. Andrabi and N. Ullah. 2011. Storage of Nili-Ravi Buffalo (Bulbalus bubalis) semen in skim milk extender supplemented with ascorbic acid and $\alpha$ tocopherol. J. Zool. 43 (2): 273-277.

Aurich, J. E., U. Schoneher, H. Hoppe and C. Aurich. 1997. Effect of antioxidants on motility and membrane integrity of chilled-stored stallion semen. Theriogenology 48 (2) : 185-192.

Feradis. 2009. Peranan antioksidan dalam pembekuan semen. J. Peternnakan. 6 (2) : 63-70

Hafez, E. S. E. dan B. Hafez. 2000. Reproduction in Farm Animals. $7^{\text {th }}$ Edition. Blackwell Publishing. South Carolina, USA.

Lubis, T. M., Dasrul, C. N. Thasmi dan T. Akbar. 2014. Efektivitas penambahan vitamin $\mathrm{C}$ dalam pengencer susu skim kuning telur terhadap kualitas spermatozoa kambing boer setelah penyimpanan dingin. J. Sains Pertanian. 3(1) : 347-361.

Maulida, A. N. 2014. Evaluasi Post Thawing Motility (PTM) pada Semen Beku Sapi Simental Produksi BIB Ungaran di Kabupaten Wonosobo dan Purbalingga. Fakultas Peternakan dan Pertanian, Universitas Diponegoro. Semarang. (Skripsi).

Mumu, M. I. 2009. Viabilitas semen sapi simmental yang dibekukan menggunakan krioprotektan gliserol. J. Agroland. 16(2) : 172-179.

Rizal, M., M. R. Toelihere, T. L. Yusuf, B. Purwantara dan P. Sihombing. 2002. Kualitas semen beku domba Garut dalam berbagai konsentrasi gliserol. J. Ilmu Ternak dan Veteriner. 7 (3): 194199.

Rosmaidar, Dasrul dan T. M. Lubis. 2013. Pengaruh penambahan sari buah tomat 
dalam media pengencer teradap motilitas dan viabilitas spermatozoa kambing Boer yang disimpan pada suhu $3-5^{\circ} \mathrm{C}$. J. Ilmiah Peternakan. 1 (1): 7-17.

Sastrosupadi, A. 2000. Rancangan Percobaan Praktis Bidang Pertanian. Kanisius, Yogyakarta. 220-222.

Standar Nasional Indonesia. 2017. Semen Beku Bagian 1 (Sapi). 4869-1:2017 Badan Standarisasi Nasional, Jakarta.

Savitri, F. K., S. Suharyati dan Siswanto. 2014. Kualitas semen beku sapi bali dengan penambahan berbagai dosis vitamin $C$ pada bahan pengencer skim kuning telur. J. Ilmiah Peternakan Terpadu. 2 (3) : 30-36.

Suharyati S. dan M. Hartono. 2011. Preservasi dan kripreservasi semen sapi
Limousin dalam berbagai bahan pengencer. J. Kedokteran Hewan. 5 (2) : 53-58.

Sumeidiana, I., S. Wuwuh dan E. Mawarti. 2007. Volume semen dan konsentrasi sperma sapi Simmental, Limousindan Brahman di Balai Inseminasi Buatan Ungaran. J. Indon. Tropic. Anim. Agric. 32 (2): 131-137.

Tambing, S. N., M. R. Toelihere, T. L. Yusuf dan I. K. Sutama. 2000. Pengaruh gliserol dalam pengencer tris terhadap kualitas semen beku kambing peranakan etawah. J. Ilmu Ternak dan Veteriner. 5 (2): 1-8.

Wiratri, V. D. B., T. Susilawati dan S. Wahjuningsih. 2014. Kualitas semen sapi Limousin pada pengencer yang berbeda selama pendinginan. J. Ternak Tropika. 15 (1) : 13-20. 